\title{
La devoción mariana en la Orden de Predicadores. Una narrativa hermenéutico-teológica"
}

\author{
Pedro José Díaz Camacho**
}

Recibido: 1 de noviembre de 2015 • Aprobado: 8 de diciembre de 2015

\section{Resumen}

En este escrito se indagan, analizan y exponen algunas narrativas y cuestiones sobre la devoción mariana en la Orden de Predicadores, desde el punto de vista de las tradiciones históricas, la reflexión teológica y las prácticas devocionales cultivadas y promovidas en el ámbito de la familia dominicana a través de la historia, pero no se aborda la cuestión más amplia y compleja de los desarrollos doctrinales de la mariología y sus vicisitudes históricas en la Orden de Predicadores.

Palabras clave: religiosidad popular, devoción mariana, prácticas devocionales, tradiciones dominicanas.

* El artículo es resultado de la investigación del autor. DOI: http://dx.doi.org/10.15332/ s2011-9771.2016.0001.06

** Posdotorado en Narrativa y Ciencia, Doctor en Teología, Magister en Teología, Especialista en Ecumenismo y Nuevos Movimientos Religiosos, Teólogo. Ha sido docente de Teología y de Humanidades y directivo académico de la Universidad Santo Tomás. Correo elctrónico: fraypedrodiaz@usantotomas.edu.co 


\title{
Devotion to Virgin Mary in the Dominican Order. A theological-hermeneutic narrative
}

\begin{abstract}
This paper inquires, analizes and exposes some narratives and questions on Marian devotion at the O.P. from the view point of traditions, theological reflection. Also, it analyses from devotional practices raised by Dominican family through history. However, the biggest and most complex issue of Mariology development, its historical viscitudes at the Order are not addressed on this paper.
\end{abstract}

Keywords: Popular religiosity, Marian devotion, devotional practices, Dominican traditions.

\section{La dévotion mariale dans l'Ordre des Prédicateurs. Une narration herméneutique - théologique}

\section{Résumé}

Dans cet écrit on recherche, analyse et expose quelques narrations et interrogations au sujet de la dévotion mariale dans l'Ordre des Prédicateurs, à partir du point de vue des traditions historiques, la réflexion théologique et les pratiques de dévotion cultivées et encouragées dans le domaine de la famille dominicaine à travers l'histoire, mais la question plus ample et complexe à propos des développements des doctrines mariales et ses vicissitudes historiques dans l'Ordre des Prédicateurs n'est pas abordée.

Mots-clés: Religiosité populaire, dévotion mariale, pratiques de dévotion, traditions dominicaines. 


\section{Introducción ${ }^{1}$}

Desde sus orígenes, la historia de la Orden de Predicadores ha estado asociada al reconocimiento de la figura de María como modelo de vida creyente, protectora e intercesora permanente, según se expresa en los documentos que tratan sobre los orígenes y los primeros tiempos de la comunidad fundada por Santo Domingo de Guzmán, como lo demuestra también el especial interés de los frailes y demás miembros de la Familia Dominicana por cultivar tanto la reflexión teológica como la difusión de la piedad mariana al interior de las comunidades y, a través del ministerio de la predicación, de los escritos y de las diversas prácticas pastorales.

Con sobrada razón, se suele relacionar a la Orden de Predicadores, fundada por Santo Domingo de Guzmán y confirmada por el papa Honorio III en 1216, con la devoción a la Virgen María, especialmente en la advocación del rosario y con la práctica de la oración que lleva esta denominación, lo cual tiene su fundamento histórico y documental, y cuenta con un explícito y claro aval institucional en las Constituciones de los frailes y en otros documentos oficiales de la Orden y de su tradición espiritual y pastoral.

Para estructurar esta reflexión, se han considerado algunas referencias históricas, teológicas, hermenéuticas, organizacionales y regulatorias en orden a dar razón de la relación entre la Comunidad Dominicana con lo que se denomina la devoción mariana. Para ello apelamos a los documentos y leyendas antiguas relacionadas con el origen de la Orden y su vinculación con la figura de María, a algunos autores, escritos y testimonios teológicos y espirituales de distintas épocas de la tradición dominicana y a los hechos especialmente significativos relacionados con las prácticas y las organizaciones de carácter mariano dentro de la misma comunidad o bajo su influencia.

En sentido general, la devoción es una manifestación de la religiosidad; es decir, de la experiencia religiosa que expresa la relación con Dios y, por extensión analógica, con la Virgen María y los santos, para rendir el culto que corresponde, a través de la oración y otras prácticas propias de dicha relación, en el ámbito de la fe cristiana.

1 Este tema fue desarrollado y presentado, en forma más resumida, como ponencia en el IV Congreso Internacional de Teología Mariana (Bogotá, Universidad Santo Tomás, Octubre 9-11 de 2015). 
En consecuencia, se considera que la devoción es un acto de la religión, según Santo Tomás (S.Th, II-II, q. 80), y se define como la voluntad de entregarse con prontitud a lo que se relaciona con el servicio de Dios (S. Th, II-II, q.82, a. 1 y 2). En este caso a lo que refiere a la relación con la Virgen María, Madre de Dios, desde el punto de vista de lo que se denomina: fervor religioso, veneración y piedad, adhesión afectuosa, celo por cultivar prácticas de piedad hacia ella, y expresiones similares, dentro de lo que Santo Tomás y la tradición teológica ha distinguido como culto de latría que solo se ha de tributar a Dios (S.Th, II-II, q. 81, a 7), es decir, el culto divino que se ofrece con el corazón, con la boca y con las obras (Suma contra Gentiles, L. 3, c. 120), y que cuando se dirige a la Virgen María y a los santos recibe otras denominaciones (dulía o hiperdulía), que no corresponden a lo que es la "adoración" propiamente dicha. Al hablar de la devoción a María, se hace, pues, un uso analógico de esta expresión (Martín, 1988, pp. 574-577).

\section{La devoción mariana en los orígenes de la Orden de Predicadores}

\subsection{Antecedentes y eventos históricos de la devoción mariana}

Las narrativas mariológicas, la reflexión teológica sobre la figura de María y la devoción mariana tienen una historia extensa y antecedentes muy significativos en relación con la fundación de la Orden de Predicadores. Los Padres de la Iglesia, tanto de oriente como de occidente, desde el siglo II en adelante, abordaron algunos aspectos relacionados con la Virgen María, generalmente unidos a los comentarios los evangelios, incluyendo los apócrifos, y a los debates y enseñanzas sobre la Encarnación; lo mismo se encuentra en los concilios, los credos -símbolos-, los himnos, la iconografía, la homilética, las cartas y los formularios litúrgicos antiguos. Contamos con una larga y fructífera tradición mariana.

Después del Concilio de Efeso (431), con la declaración solemne de la maternidad divina de María, se expandió por todo el mundo cristiano el reconocimiento de la Virgen María como un gran signo y modelo de vida creyente, de santidad y de intercesión, todo lo cual acrecentó la devoción hacia ella y se expresó de diversas maneras; los debates sobre la maternidad divina de María, sobre su virginidad, su concepción inmaculada y su tránsito o dormición, así como sobre su papel en la obra redentora de Cristo, tienen una larga trayectoria 
en la historia de la teología cristiana, en oriente y occidente, de lo cual se trata en los cursos y escritos teológicos sobre "Mariología". Un siglo antes de la fundación dominicana, san Bernardo de Claraval (1091-1153), había promovido con especial empeño apostólico la devoción mariana en Europa. En "la atmósfera espiritual de la cristiandad medieval" y, por supuesto, en tiempos de Santo Domingo de Guzmán y de los comienzos de la Orden, la devoción filial mariana es uno de los componentes sobresalientes de la religiosidad popular que proliferaba en aquellos tiempos.

\subsection{La devoción mariana y los orígenes dominicanos}

La experiencia cristiana de Santo Domingo de Guzmán y los orígenes de la Orden de Predicadores están marcados por diversos hechos y narraciones relacionadas con la presencia de la Virgen María en la vida del Fundador y de los primeros frailes y la especial devoción de éstos hacia Ella, hasta el punto de llegar a expresar ese vínculo en la fórmula de la profesión de los frailes prometiendo obediencia a Dios y "a la bienaventurada Virgen María", como se lee en el libro de las Constituciones de los frailes ${ }^{2}$, donde se afirma que: En nuestra profesión, movidos de piedad filial, prometemos también someternos a la Virgen María, Madre de Dios, como madre benevolentísima de nuestra Orden (LCO, 189, § III)... Yo, fray NN., hago profesión y prometo obediencia a Dios y a la bienaventurada María y al bienaventurado Domingo y a ti, Fray... (LCO, 199,§ I). Lo cual significa entrega al servicio de ella y confianza en su protección maternal.

Distintas narraciones y documentos de origen dominicano hablan sobre la especial relación de la Virgen María con los frailes y sus comunidades en los comienzos de la Orden Dominicana, según se expone en seguida.

En efecto, Santo Domingo cultivó y transmitió un especial afecto y devoción a la Virgen María, y así lo han referido los escritos antiguos y lo ha plasmado el arte, particularmente en torno al Rosario y al canto de la "Salve" al finalizar el día, cuando se reconoce y confía en una especial protección sobre la comunidad, como "patrona especial" según lo escribía Fray Humberto de Romanis, uno de los sucesores de Santo Domingo en el gobierno de la Orden, así:

2 El Libro de las Constituciones de los Frailes se citará así: LCO, con la numeración correspondiente. 
Tenemos muchos motivos para pensar que la Virgen María es Patrona especial de nuestra Orden, apoyándonos en hechos ciertos acaecidos en los primeros tiempos de la Orden. Por cuanto por mí mismo oí y por otras muchas cosas ya escritas en "Las vidas de los frailes" se ve que ella es madre especial de esta Orden fundada para alabar, bendecir y predicar a su Hijo y por esto ella la guía, la promueve y la defiende. Precisamente el bienaventurado Domingo en sus oraciones encomendaba su Orden a la misma Virgen, teniéndola por especial patrona, como se cuenta en la "Nueva leyenda", y éste es el motivo de por qué acudimos cada día a ella como a madre en la procesión al canto de la salve, como asimismo hacemos memoria del bienaventurado Domingo con el canto de su antífona (De Romanis, 1889, p. 134). ${ }^{3}$

Enseguida vamos a aludir brevemente a algunas de las narraciones mencionadas.

a. Los relatos y documentos sobre los primeros frailes hacen un amplio despliegue sobre el ingreso del maestro Reginaldo de Orléans a la Orden, quien "era un hombre que gozaba de gran estima, docto e ilustre; había regentado durante cinco años la cátedra de derecho canónico en la Universidad de París" (Jordán, 57$57)^{4}$ y se menciona la especial presencia de la Virgen María en su decisión de hacerse fraile, habiendo superado milagrosamente una grave enfermedad contraída en Roma cuando planeaba viajar a Tierra Santa, quien llegó a ser un gran predicador y un gran promotor de nuevas vocaciones, alcanzando un reconocido nivel de santidad, (Jordán, n 56 - 57; Ferrando, n.33 - 37; de Cerrato, n.16; de Orvieto, n. 31; Vicaire, 347 y 399). Fray Reginaldo está incluido en el calendario litúrgico de la Orden como beato el día 12 de febrero. Una narración parecida sucede en torno a un tal fray Enrique, un ilustre canónigo de origen holandés, quien ingresó a la Orden gracias a la intercesión de la Virgen María y llegó a ser un reconocido predicador y prior del convento de Colonia (Alemania), compañero y amigo de Jordán de Sajonia (Jordán, 56-85, Vicaire, 423 y 469). El ingreso de estos dos reconocidos personajes, entre otros, a la Orden se atribuye a la intervención especial de la Virgen María, según varios relatos de los comienzos.

3 La cita está tomada del Misal OP, 8 de mayo, en la fiesta del Patrocinio de la Virgen en la OP.

4 Para las citas de Jordán de Sajonia y de los demás cronistas, se mencionan los autores con la numeración correspondiente en la obra referida en la bibliografía. 
b. Diversos sucesos relacionados con la muerte de Santo Domingo están asociados a supuestas manifestaciones especiales de la Virgen María (visiones y apariciones) como fruto de la gran devoción que él cultivo a nivel personal e inculcó a sus frailes, sobre lo cual los documentos hacen amplios relatos relacionados con la protección de la Virgen sobre los frailes y sobre toda la Orden (Cf. Jordán, 95; Ferrando, 51; de Orvieto, 64; de Cerrato, 48).

Después de la muerte de Santo Domingo, se narran diversas situaciones que atribulaban a los frailes y les causaban dudas vocacionales y sufrimientos espirituales y morales, luego de lo cual se dice:

"Finalmente, recordando que santo Domingo había encomendado el cuidado de la Orden a la Virgen María, como a su patrona especial, y considerando también que el Señor en el Evangelio no les había dejado más que un apoyo, es decir, a su Madre, se acogieron a la piadosísima Virgen, como a esperanza única, y determinaron que en su honor se hiciera una solemne procesión hasta su altar después de las completas. Todos los frailes se reunirían para cantar devotamente la antífona Salve Regina [...]. Reconociendo, pues, los frailes que había recibido tantos beneficios de la Virgen Madre de misericordia, por el canto de la antífona Salve Regina, y también con la esperanza de recibir en lo sucesivo otros muchos, determinaron que se observara por toda la Orden este modo de hacer la mencionada procesión" (de Cerrato, 48; Cf. de Frachet, I, cap. 7; Jordán, 120, Vicaire, 559-560).

Al final del canto de la salve Regina, se proclama un responso que invoca la protección de la Virgen, así: Dignare me laudare te Virgo sacrata./ Da mihi virtutem contra hostes tuos. Concédeme que te alabe Virgen sagrada./ Dame fuerza contra tus enemigos. También suele cantarse un breve himno que exalta la pureza de María y su gracia intercesora: Inviolata, intacta et casta es María..., así como el más conocido: Ave maris stella... Textos piadosos que han formado parte de la tradición orante de los frailes dominicos.

La mencionada procesión mariana nocturna, para culminar el rezo de las Completas, el cual corresponde una de las tradiciones y ritos litúrgicos de gran arraigo y recordación a lo largo de la historia dominicana, la cual tiene especial esplendor en los conventos de formación y genera gran impacto en los laicos cuando tienen la oportunidad de participar en ella o de observar esta práctica devocional en honor de la Virgen, la cual se ha conservado inmodificable durante ocho siglos. Suele representarse la escena en una pintura en la que aparece la 
Virgen mientras se hace una aspersión de agua bendita a los frailes que cantan la "salve regina".

c. Gerardo de Frachet, uno de los más connotados cronistas de los comienzos de la Orden, que había comenzado su escrito con el tema titulado "Cómo nuestra señora obtuvo de su Hijo la Orden de Predicadores" (De Frachet, 1987), más adelante recoge y desarrolla 22 narraciones sobre "Cómo nuestra Señora ama y protege con singular afecto a la Orden" (De Frachet, 1987). Esta experiencia comunitaria de los comienzos dominicanos dio origen a la fiesta del Patrocinio de la Virgen María sobre la Orden que se registra en el calendario dominicano el día 8 de mayo, la cual anteriormente se celebraba el 22 de diciembre (Misal O. P.).

d. Las primitivas Constituciones de los frailes hablan de cómo éstos se deben levantar al toque de la campana y rezar "los Maitines de la bienaventurada Virgen, según el tiempo", e indica las veces que durante la oración han de hacer inclinación corporal, como signo de especial reverencia. "Igualmente, en el Capítulo (o reunión de frailes), a la oración Santa María, y siempre que se nombra a la bienaventurada Virgen en las oraciones" (Constituciones antiguas, Distinción primera, 1. De los Maitines).

e. Fray Enrique Lacordaire (1802-1861), restaurador de la Orden en Francia a mediados del siglo XIX, nos recuerda varias narraciones relacionadas con la devoción a la Virgen que él había estudiado durante su noviciado en Roma y las dejó escritas en su obra: Vida de Santo Domingo, así:

Sobre la fundación del monasterio de Prulla, dedicado a la Virgen, dice:

Había en Prulla, aldea situada en una llanura entre Fanjeaux y Montreal, al pie de los Pirineos, una Iglesia dedicada y la Santísima Virgen y célebre de antiguo por la veneración de los pueblos. Domingo era devoto de Nuestra Señora de Prulla: ante ella solía orar durante sus excursiones apostólicas. Cuando subía o bajaba las primeras colinas de los Pirineos, le aparecía el humilde santuario de Prulla, a la entrada del Laguedoc, como un lugar de esperanza y de consuelo. Allí, al lado de la iglesia, estableció su monasterio, con el asentimiento y ayuda del obispo Fulco, recién promovido a la sede tolosana (Lacordaire, 2002, 98) [...]. Terminados los preparativos, el 27 de diciembre de 2006, día de San Juan Evangelista, tuvo Domingo el gozo de abrir las puertas de Nuestra Señora de Prulla a varias señoras y jóvenes que deseaban consagrarse a Dios bajo su dirección (Lacordaire, 2002, p. 99). 
Y continúa: "Bajo el amparo de la Virgen funda la Orden de Predicadores" (Lacordaire, 2002).

La guerra, por su duración y alternativas, parecía obstáculo casi invencible al designio constante de Domingo, cual era fundar una orden religiosa consagrada al ministerio de la predicación. Y así, no cesaba de pedir a Dios el restablecimiento de la paz, y con objeto de obtenerla y acelerar el triunfo de la fe, instituyó, no sin secreta inspiración, esa fórmula de orar tan extendida en la Iglesia universal con el nombre de Rosario (Lacordaire, 2002, p. 107).

A propósito de la "Enfermedad y muerte de Domingo", dice el mismo autor: Por consejo de los médicos, y pensando que le convendría el cambio de aire, le llevaron a Santa María del Monte, iglesia dedicada a la Santísima Virgen María en un alto próximo a Bolonia (Lacordaire, 2002, p. 185).

Son abundantes las narraciones acerca de la vida de los primeros frailes en las que se menciona la presencia protectora constante de la Virgen María, lo cual explica el arraigo de la devoción mariana en la Orden y su permanencia a lo largo de la historia de la comunidad de los frailes y demás miembros de la Familia Dominicana.

\section{La devoción mariana institucionalizada en la Orden}

La devoción a la Virgen María no ha sido solo una experiencia personal, espontánea y libre de algunos frailes en los orígenes o en algunas épocas y lugares, ni dejada a la subjetividad o inspiración individual. Es también un hecho canónico y legalmente afirmado, recomendado, promovido y cuidado. Por esta razón recogemos aquí los textos más explícitos y vigentes en las Constituciones de los Frailes Predicadores:

a. Como ya se ha mencionado: En nuestra profesión, movidos de piedad filial, prometemos también someternos a la Virgen María, Madre de Dios, como madre benevolentísima de nuestra Orden (LCO, 189, § III)... Yo, fray NN., hago profesión y prometo obediencia a Dios y a la bienaventurada María y al bienaventurado Domingo y a ti, Fray... (LCO, 199, § I)

Se recomienda a los frailes que: 
"Aprecien cordialmente la tradicional devoción de nuestra Orden a la Virgen Madre de Dios, Reina de los Apóstoles y ejemplo de meditación de las palabras de Cristo y de docilidad en la propia misión.

Reciten cada día la tercera parte del Rosario, en común o privadamente, según determinación del Capítulo Provincial y teniendo en cuenta su conveniente ordenación a la liturgia. Esta forma de orar nos lleva a la contemplación del misterio de la salvación, en el que la Virgen María se une intimamente a la obra de su Hijo" (LCO, 67, § II).

"Puesto que el Rosario es camino para contemplar los misterios de Cristo y escuela para formar la vida evangélica, debe ser considerado como un modo de predicación conforme con la Orden, en el cual se expone la doctrina de la fe a la luz de la participación de la bienaventurada Virgen María en el misterio de Cristo y de la Iglesia.

Así, pues, los frailes prediquen fervientemente la práctica del Rosario que debe ser tenida como característica peculiar de la Orden, a fin de que cada día tenga mayor vitalidad, y promuevan sus asociaciones" (LCO, 129; Cf. Cap. México, 258, Cap. Caleruega, 129).

Se dice, además, que el oficio de maestro de novicios: “[...]lo desempeñe diligente y fielmente, con el auxilio de la divina gracia y bajo el patrocinio de la bienaventurada Virgen María y de nuestro Padre santo Domingo". (Cf. LCO182, § I; 213 § III, Letras de nombramiento del maestro de novicios, apéndice 7).

El Maestro (de novicios)...enséñeles (a ellos) que seguir a Cristo es la regla suprema de nuestra vida; a sentir con la Iglesia, a conocer y conservar el espíritu de santo Domingo y las sanas tradiciones de la Orden, a conocer oportunamente los signos de los tiempos y a valorarlos a la luz de la fe (LCO, 214, § I, resaltado nuestro). Entre esas "sanas tradiciones de la Orden" debemos considerar la devoción a la Virgen María expresada de diversas maneras, como en las mismas Constituciones se expone.

Tratando sobre la guarda de la castidad, se recomienda a los frailes: Robustézcanla (la castidad) también con un filial amor y devoción hacia la Bienaventurada Virgen María, Madre de Dios (LCO, 28, § I).

Además de los textos y directrices constitucionales, suele darse también recomendaciones acerca del cultivo de la devoción a la Virgen María, a través de las autoridades colegiadas de los Capítulos Generales (reuniones internacionales) y 
Provinciales (reuniones nacionales) que sesionan con periodicidad, mantienen y estimulan los valores espirituales de la tradición dominicana.

Como muestra de ello, dos ejemplos: La tradición de la Orden nos vincula a la oración y al apostolado de Rosario, que en numerosas Provincias está ya bien desarrollado. Pedimos al Promotor General del Rosario que favorezca el intercambio entre ellas para compartir experiencias en este ámbito de la predicación y que procure extender sus beneficios al conjunto de la Orden (Capítulo General de Bogotá, 2007, actas, 96). Es obvio que se reconoce que existe en la Orden un oficio que se denomina "Promotor General del Rosario", como se ha mencionado en el texto anterior.

Continúa el texto del Capítulo General de Bogotá: Nuestros formandos esperan que, quienes llevamos más años en la Orden, les transmitamos la fidelidad en el seguimiento de Jesús y el amor a María, al estilo de Domingo (Ibid., actas, 199).

A propósito de las directrices para la formación de los novicios se dice en otro documento oficial de la Orden: La formación debe ofrecer también una iniciación práctica a la liturgia, a la práctica sacramental y al estudio del papel de María, Madre de Dios, tal como se encuentra en la rica tradición de la Orden (LCO, 129; Ratio Formationis Generalis, 1988, n. 62).

Hasta aquí algunos textos de la legislación dominicana.

b. Por otra parte, es ilustrativo e interesante recordar que algunos conventos, parroquias e instituciones educativas y pastorales de origen dominicano o regentadas por los frailes llevan el nombre de la Virgen, especialmente en la advocación de nuestra Señora del Rosario, como testimonio de su origen dominicano y rasgo de su identidad institucional, así:

La Provincia de Nuestra Señora del Rosario (Filipinas), Provincia de la Asunción de la Virgen María (Australia), Provincia de la Anunciación de la Virgen María (Suiza), Provincia Reina de los Mártires (Vietnam); en Colombia, el Colegio Mayor del Rosario (Universidad fundada por el obispo dominico Fray Cristóbal de Torres, el 18 de diciembre de 1653), las Parroquia que en Colombia llevan el nombre de nuestra Señora del Rosario de Chiquinquirá. El sello antiguo de la Universidad Santo Tomás de Colombia representa al Santo patrono postrado en actitud contemplativa en medio de la imagen de Cristo crucificado y de la Virgen María, y todo el escudo está circundado por un rosario. Se mencionan las anteriores entidades solo como una muestra de esta relación entre instituciones dominicanas y el nombre de la Virgen María. Igualmente es importante tener en cuenta que muchos monasterios y congregaciones de religiosas e institutos de vida apostólica 
fundados o asociados a la Orden, llevan el nombre mariano en su denominación (La Presentación, la Anunciata, Nazaret, Betania, Rosario, etc.).

La Orden Dominicana, además, regenta pastoralmente algunos santuarios marianos: Madonna dell'Arco (Nápoles), La Virgen del Camino (León- España), Nuestra Señora de Montesclaros (España-Cantabria), Nuestra Señora del Rosario de Chiquinquirá (Colombia), santuario del Santísimo Rosario (Lima), Reina del Rosario de Fátima (Montreal-Canadá), Nuestra Señora del Rosario (Santiago-Chile), la Basílica Santa María la Mayor (Roma), denominada "palacio de María", y considerada como el primer santuario mariano en el mundo, encomendado actualmente al cuidado de los frailes dominicos, especialmente para el ministerio de la penitencia y la reconciliación, entre otros.

\section{Algunos testimonios y aspectos teológicos en la tradición dominicana}

La investigación histórica, la reflexión teológica y la experiencia espiritual de los frailes ha recogido y elaborado esta devoción mariana y la ha plasmado en sus escritos, libros, tratados, obras de arte, revistas, ensayos y folletos de distinta condición, sobre lo cual aportamos, como ejemplo, los nombres de algunos de autores, teniendo en cuenta que aquí no se trata de recopilar una muestra de la bibliografía sobre mariología desde la perspectiva dominicana, sino algunos testimonios de las diversas formas como los frailes han expresado su relación con María.

Alberto Magno (1206-1280). Ilustre maestro de Tomás de Aquino en la Universidad de París y defensor de su discípulo cuando los contradictores querían condenar algunas de sus enseñanzas. Dentro de sus innumerables obras teológicas y comentarios bíblicos, dedicó algunos escritos a la Virgen María, como el "Mariale", en torno al comentario sobre el misterio de la Anunciación y el cántico del Magnificat, en el que expone varios asuntos de la doctrina sobre María. Se refiere a la santidad y maternidad de la Virgen María, a sus prerrogativas frente a los demás seres de la creación, la confianza profunda en su ayuda, utiliza muchas expresiones de alabanza con imágenes simbólicas, reconoce una especial mediación de la Virgen para recibir, a través de ella la gracia divina, por lo cual dice que la expresión Madre de misericordia es el nombre más propio de la Virgen María. San Alberto decía: 
La bienaventurada Virgen María es llamada propiamente puerta del cielo, pues por ella salieron todas las gracias creadas e increadas que llegaron y han de llegar a este mundo, ya que ella es la madre de todos los bienes, madre de la gracia y madre de misericordia, y aún la misma gracia increada como acueducto salió por ella y vino al mundo. Igualmente por ella pasaron todos los bienes que del cielo a la tierra bajaron (En: Gelabert, 1958, p. 1132).

A este propósito de la mediación de María, el calendario dominicano anterior al Concilio Vaticano II celebraba la Fiesta de la Santísima Virgen María, Mediadora de todas las gracias, el 7 de junio. La Orden celebra la fiesta litúrgica de San Alberto Magno el 15 de noviembre.

Tomás de Aquino (1225-1274). Los principales asuntos tratados por Santo Tomás se hallan en los comentarios a la Sagrada Escritura, a los libros de las Sentencias de Pedro Lombardo, la Suma Teológica, en el contexto de la Cristología, (S.Th. III, q. 27-30) y el comentario a la salutación angélica o Ave María. Las cuestiones centrales que aborda se refieren a la maternidad divina de María, su relación con la redención, la virginidad de María, los privilegios, la sobreabundancia de la gracia en ella y la Asunción, en un esfuerzo por mantener una armonía teológica entre el misterio de la virgen-madre y el misterio del hombre-Dios, así como la dimensión universal de la salvación, apoyado en la revelación divina y en la enseñanza de los Padres de la Iglesia. Se celebra su fiesta el 28 de enero, aunque tradicionalmente se celebró el 7 de marzo, fecha de su muerte.

San Pedro de Verona (+1252). Había recibido el hábito dominicano de manos del santo fundador y fue un insigne predicador y gran devoto de la Virgen María, devoción que extendió entre los seglares a quienes motivaba al compromiso en el apostolado. Instituyó "las Cofradías para la alabanza de la Bienaventurada Virgen María", como una forma de apostolado en el pueblo; por otra parte, se considera como el primer mártir de la Orden, la cual celebra su memoria el 4 de junio.

Enrique Susón (+1366). Es uno de los insignes místicos de la Orden Dominicana; cultivó una profunda y tierna devoción a la Virgen María, la cual formó parte de su reconocida experiencia mística, según se expresa en varios pasajes de su autobiografía espiritual. Se dice que celebraba el mes de mayo en honor de la Virgen con especial cuidado y ternura. En el calendario dominicano se le recuerda y celebra como bienaventurado o beato el 23 de enero.

Fra Angélico, Juan de Fiésole (1395-1455), reconocido especialmente en el arte de la pintura, fue un hombre profundamente piadoso que "Con gran fidelidad a la misión religiosa de su vida proponía con su arte celestial los divinos misterios que 
contemplaba en la oración y en el estudio de la sagrada verdad" (Liturgia de las Horas, $\mathrm{OP})$; supo plasmar en diversas obras la figura de María en su relación con Santo Domingo y con la comunidad, así como la devoción al rosario. Pintó varias veces la Anunciación, la Virgen con el Niño, en el pesebre, ante el crucificado y en el sepulcro, la visitación, la dormición, el desposorio con san José, la huida a Egipto, la coronación, entre sus muchas representaciones pictóricas de la Virgen María, para expresar así la tradición dominicana en relación con la devoción mariana, obras que se observan en el convento de san Marcos de Florencia y en otros lugares. La Iglesia celebra su fiesta como beato el 18 de febrero.

Alano de la Roche, o Rupe (1428-1478): Para nuestro tema, debemos anotar que, en relación con el rosario, se dice que "Definió su estructura y propagó su práctica de modo extraordinario y eficaz". Se le reconoce como el fundador de la primera cofradía del rosario, propiamente dicha. (Misal OP, fiesta del Rosario).

San Pio V, (1504-1572). Con el auxilio de la Virgen María mediante la devoción del rosario, libró a la Iglesia de la invasión de sus enemigos; fue gran propagador del Rosario. Mediante la bula Consueverunt Romani Pontifices, del 17 de diciembre de 1569 determinó la forma definitiva del rosario actual, y en 1572 instituyó la fiesta de "la bienaventurada Virgen María de la victoria", que luego se denominó del Rosario; su cuerpo descansa a los pies de la Virgen en la Basílica Santa María la Mayor (Roma), como lo había pedido, según su acendrada devoción a la Virgen. La Orden celebra su memoria litúrgica el 30 de abril.

Se puede decir que, en lo que se ha denominado la "Contrarreforma", y en el ámbito general de la Iglesia en Occidente, se desarrolló una mariología bastante triunfalista, maximalista y un poco autónoma, si se quiere, durante largo tiempo.

Bartolomé Longo (1841-1926). Fue un laico dominico italiano que trabajó mucho en la difusión de la devoción mariana a través del rosario, fundó la basílica de nuestra Señora del rosario de Pompeya (1876). La Orden hace memoria litúrgica de él el 6 de octubre y lo reconoce como "apóstol del rosario".

En Colombia han sobresalido varios frailes por su especial devoción y dedicación al apostolado mariano, particularmente con la promoción del rosario y los escritos en torno al santuario de la Virgen del Rosario de Chiquinquirá, promoviendo su culto y difundiendo la práctica del rezo del rosario, especialmente con la modalidad del "rosario de aurora", en misiones populares y en peregrinaciones (Fr. Andrés Mesanza, Fr. Domingo Méndez, Fr. Eriberto Santamaría, Fr. Luis FranciscoTéllez, Monseñor Leonardo Gómez, O. P., entre otros). 


\section{Testimonios litúrgicos y pastorales}

Cabe mencionar algunas de las fiestas y prácticas litúrgicas o devocionales asociadas a la tradición dominicana en torno a la devoción mariana.

La fiesta de la Virgen del Rosario, que se celebra en el mes de octubre, recordando la victoria de la batalla de Lepanto (1572), como ya se mencionó. El rosario o camándula ha formado parte del vestuario como componente del hábito de los frailes y algunas comunidades femeninas, que lo han llevado a veces al cuello, a la cintura o en el bolsillo.

La fiesta del Patrocinio de la Virgen María sobre la Orden, que se celebra en el calendario dominicano el 8 de mayo, como ya se mencionó.

Estas dos formas de manifestar la devoción mariana (el rosario y el patrocinio de la Virgen), son también las dos expresiones iconográficas más certeras y constantes de la devoción mariana en la Orden. En una contemplamos a la Virgen cubriendo con su manto protector a los frailes y monjas de la Orden y en la otra a la Virgen entregando el rosario a Santo Domingo.

Por otra parte, el reconocimiento de la Virgen como Reina, ha sido muy frecuente en la tradición dominicana, recogiendo las enseñanzas de los santos Padres: Reina de la misericordia, además de reina de la paz y del amor. En tiempos pasados, la Orden culminaba el mes de mayo con la fiesta de la "Virgen María Reina", el 31 de mayo. Ahora se celebra en esa fecha La Visitación de la Virgen, en el calendario actual. Pero se ha mantenido la costumbre de este reconocimiento, con la práctica de la coronación de las imágenes de la Virgen y su proclamación como reina, como se reza: Salve reina y madre de misericordia, y se canta en Colombia: Reina de Colombia, por siempre serás. Y como la han pintado artistas, como Fra Angélico y otros.

En la tradición mariana ha sido muy importante el denominado Oficio "Parvo" de la Bienaventurada Virgen María, de larga tradición monástica (Siglo XI) y dominicana, que al principio (Siglo XIII) lo rezaban los frailes en paralelo con el llamado "oficio divino" (actual Liturgia de las horas), también lo rezaban los laicos (llamados terciarios dominicos hasta mediados del siglo XX) y los hermanos cooperadores, hasta cuando se impuso la liturgia de las horas en lengua vernácula y se fue dando la posibilidad de participación de ellos en la renovada liturgia de las horas (Vicaire, 1964, p. 613). Esta forma de oración comunitaria constaba de Maitines y Laudes, Prima, Tercia, Sexta, Nona, Vísperas y Completas, y que en tiempos de Santo Domingo se iniciaba y terminaba con el rezo del "Ave María" (Orden Tercera Seglar de Santo Domingo, 1960, p. 40). 
Otra práctica de la larga tradición devocional mariana en la Orden era la procesión mensual en honor de la Virgen del Rosario dentro de las Iglesias dominicanas, que se llevaba a cabo el primer domingo de cada mes, con rito establecido en el Procesionario de la Orden, práctica que perduró hasta la reforma litúrgica del Concilio vaticano II (Processionarium, p. 303).

Los Dominicos han emprendido y acompañado diversas misiones populares y peregrinaciones bajo el patrocinio de la Virgen María, como las realizadas en distintas épocas con la Virgen del Rosario de Chiquinquirá, la más reciente presidida por Monseñor Leonardo Gómez a lo largo del río Magdalena (Colombia) en 2013, con el anuncio del perdón, la reconciliación y la paz, para promover el rezo del rosario con la gente de los pueblos ribereños, especialmente afectados por distintas formas de violencia, exclusión, olvido social y gubernamental.

Las novenas en honor de la Virgen, preparatorias de sus fiestas, suelen celebrarse en los santuarios dedicados a ella, y el rezo del "ángelus", especialmente al comienzo del día, al medio día y al final de la tarde, son otras prácticas frecuentes de la piedad mariana que han sido promovidas por la comunidad dominicana.

Las letanías de la Virgen, se ordenaron desde el Capítulo General de 1256, con el maestro de la Orden Humberto de Romanis, para pedir por las necesidades de la Orden y para su defensa y protección (Liturgia de las Horas, OP, 18531855) y se han cantado especialmente los sábados en la noche, para concluir el día dedicado desde antiguo a venerar a la Virgen María.

En la tradición dominicana, gozan de especial significado las capillas dedicadas a la Virgen del Rosario, como ocurre con las tres más reconocidas en nuestro contexto regional: La capilla del Rosario en el templo de Santo Domingo en Puebla, México, la del templo de Santo Domingo, en Tunja, Colombia, y la del templo de Santo Domingo en Quito, Ecuador, todas representativas del llamado barroco novohispano, y que pueden considerarse como formas visuales permanentes de catequesis y de la devoción mariana en torno a los misterios del rosario.

En todos los templos, capillas, conventos y casas religiosas de la familia dominicana se multiplican las diversas imágenes de la Virgen María, en sus distintas advocaciones y, de manera preferente, las imágenes de la Virgen del Rosario, así como los santuarios que los frailes han ido levantando en honor de la Virgen en los distintos países y provincias; igualmente las procesiones y peregrinaciones promovidas por los frailes en torno a las imágenes y santuarios marianos en distintas regiones del mundo, todo lo cual forma parte de los múltiples testimonios litúrgicos y pastorales de la devoción mariana en la Orden de Santo Domingo, como un legado y patrimonio espiritual de la Familia Dominicana. 


\section{Conclusiones}

La devoción mariana en la Orden de Predicadores se ha vivido y expresado de múltiples formas y en contextos socioculturales diversos, en el tiempo y en el espacio, tanto en el campo litúrgico como en la religiosidad popular, a través de múltiples escritos y obras de arte, el ejercicio de la predicación y la difusión del rosario, con momentos de auge, esplendor y fecundidad y en tiempos de decaimiento, descuido y pasividad. Suele reconocerse que "Los periodos de mayor renovación interna coinciden con una mayor presencia de la devoción y obras apostólicas de carácter mariano en la vida de la Orden" (González, 1994, p. 312).

La devoción a la Virgen María, como hecho pluriforme, en sus distintas características y manifestaciones, forma parte de las sanas tradiciones dominicanas y de su impronta y patrimonio espiritual, que hay que reconocer y mantener fielmente, como lo recordó el Concilio Vaticano II en el Decreto Perfectae Caritatis (n. 2, b), sobre la adecuada renovación de la vida consagrada.

Los frailes dominicos y las comunidades y grupos de la Familia Dominicana estamos llamados a redescubrir la fuerza espiritual y pastoral de la devoción mariana desde los nuevos contextos hermenéuticos, y somos interpelados por la perseverancia devocional mariana que cultiva y mantiene el pueblo fiel, en orden a cultivar este legado espiritual que ha identificado nuestra historia en la vida de la Iglesia (PC, 2, c y e).

La devoción a la Virgen, según su arraigo, consistencia bíblico-teológica y dimensión cristológica, pneumatológica y eclesial, posee una fuerza motivadora de liberación y esperanza y de estímulo al compromiso con la justicia y la paz, como se le contempla en el Magnificat y se le invoca en la salve y en las letanías lauretanas.

Los desarrollos teológicos expresados en el Concilio Vaticano II (Constitución Lumen Gentium, cap. VIII) y la exposición del papa Paulo VI en la Exhortación Apostólica Marialis Cultus (1974), entre otros documentos eclesiales recientes, recogen muchas cuestiones de la devoción mariana que la Orden dominicana ha cultivado en su larga tradición doctrinal y espiritual.

Para favorecer la armonización teológico-espiritual y pastoral entre la religiosidad popular mariana y la celebración litúrgica, la Iglesia ha establecido unos lineamientos concretos, a modo de principios y orientaciones en el Directorio sobre la piedad popular y la liturgia, bajo el título: La veneración a la santa Madre del Señor (Directorio, pp. 169-191), lineamientos que son de gran utilidad para la 
comprensión y actuación frente a la devoción mariana, algunos de los cuales se hallan expresados en las Constituciones de los frailes, según se expuso antes.

ORACIÓN: “Oh Dios, lleno de misericordia y de fidelidad, que te has dignado encomendar la Orden de Predicadores al patrocinio especial de la bienaventurada Virgen María: te pedimos humildemente nos concedas que, así como ella es para nosotros en esta vida dulzura y esperanza nuestra, así también en el momento de nuestra muerte nos presente misericordiosamente ante su Hijo Jesús" (Fiesta del Patrocinio, 8 de mayo, calendario $\mathrm{OP})$.

\section{Referencias}

Ancilli, E. (1983). Diccionario de espiritualidad. Barcelona: Herder. (Tomo I, Voz: Devoción, autor: Roberto Retti, pp. 567-572)

Bartz, G. (2000). Guido di Pietro, llamado Fra Angélico. Barcelona: Tandem Verlag GmbH

Concilio Ecuménico Vaticano II, (1962-1965) Constitución Lumen Gentium, sobre la Iglesia, Cap. VIII, n. 52-68.

Congregación para el culto divino y la disciplina de los sacramentos (2002). Directorio sobre la piedad popular y la liturgia. Principios y orientaciones. Bogotá: Conferencia Episcopal-Departamento de liturgia.

D’Amato, A. (1996). La Devoción a María en la Orden de Predicadores. Mendoza (Argentina): Vida y Misión.

De Aquino, T. (2007). Exposición de la salutación angélica llamada ordinariamente Avemaría. En: Opúsculos y cuestiones selectas, IV, Teología (2). Madrid: BAC.

. (1998). Suma Teológica, II-II, cuestión 82, aa. 1-4. (Naturaleza: Es la devoción acto especial? La devoción es acto de la religión? Causa: La contemplación o la meditación son causa de la devoción? Efectos: La alegría es efecto de la devoción? S. Th. III, q. 27-30.

De Cerrato, R. (1987). Vida de santo Domingo, En: Galmes, L. y..., pp. 336- 368, citado según numeración.

De Fiores, S. y Meo, S. (dir). (1988). Nuevo Diccionario de Mariología. Madrid: San Pablo.

De Frachet, G. (1987). Vida de los hermanos, En: Galmes, L. y..., pp. 372-655, citado según numeración. 
De Orvieto, C. (1987). Narración sobre santo Domingo, En: Galmes, L. y..., pp. 251-289, citado según numeración.

De Romanis, H. (1889). Exposición sobre las Constituciones, Opera, II, Roma.

De Sajonia, J. (1987). Orígenes de la Orden de Predicadores, En: Galmes, L. y..., pp. 82127, citado como Jordán, según numeración.

Díaz, P. J. (2001). El Rosario, una oración de inspiración evangélica y tradición dominicana, en Frailes Predicadores, una vocación al servicio del Evangelio. Bogotá: Provincia San Luis Bertrán de Colombia, p. 70-72.

. (1999). Editor. Santo Domingo de Guzmán y los orígenes de la Orden de Predicadores. Documentos y relatos. Bucaramanga: Convento de Cristo Rey (Testimonium veritatis, 3 ).

Duval, A. (1978). Síntesis histórica de la Orden de los Frailes Predicadores. Bogotá: Biblioteca dominicana, 8 .

Ferrando, P. (1987). Narración sobre Santo Domingo, En: Galmes, L. y..., pp. 221-247, citado según numeración.

Gelabert, M. (1958). Misal diario según el rito de la Orden de Predicadores. Tercera edición. Valencia: F.E.D.A.

González, A. (1994). El carisma de la vida dominicana, Salamanca: San Esteban. (La devoción a la Madre de Dios, la Virgen María, p. 305-322).

. (1981). La vida litúrgica en la Orden de Predicadores. Roma: Santa Sabina (El oficio cotidiano de la Virgen María, p. 198-209).

Hinnebusch, W. A. (2000). Breve historia de la Orden de Predicadores. Salamanca: San Esteban.

Lacordaire, H. (2002). Santo Domingo y su Orden. La vida de Santo Domingo y otros escritos del Padre Lacordaire sobre la Orden de Predicadores. Madrid: EDIBESA (Edición preparada por José A. Martínez Puche y Lorenzo Galmés Mas).

Martín, J. (1988). Devoción mariana, En: De Fiores y..., pp. 572-599.

Martínez, J. A. (2003). Diccionario teológico de Santo Tomás. Textos de la "Suma" por orden alfabético. Madrid: Edibesa. (Voces: Devoción, María, mediación, oración, principalmente).

Moretti, R. (1983). Devoción, En: Ancilli, E. Diccionario de espiritualidad, t. I. Barcelona: Herder, pp. 567-572.

Morgott, F. (1899). Mariología tomística, o sea la doctrina completa de Santo Tomás de Aquino acerca de la Virgen María, en alemán por el canónigo Francisco Morgott, profesor de Teología del Seminario de Eichst, traducida al francés y de éste al castellano para el Reproductor Eclesiástico por el Señor presbítero D. Gabino Chaves. Universidad Autónoma Nuevo León (España). 
Orden de Predicadores (1992). Catalogus Generalis Ordinis Praedicatorum. Conspectus generalis Ordinis fratrum praedicatorum necnon index monasteriorum, congregationum et fraternitatum. Roma: Curia Generalitia, Santa Sabina.

Orden de Predicadores, Constituciones antiguas de la Orden de Predicadores, (1987). En: Galmes, L. y... (1987), pp. 727- 767.

Orden de Predicadores (1996). Libro de Constituciones y Ordenaciones de la Orden de frailes Predicadores. Madrid. Se cita como LCO, con la numeración correspondiente.

Orden de Predicadores (1988). Liturgia de las horas. Propio de la Orden de Predicadores. Roma: Curia Generalitia.

Orden de Predicadores (1992). Misal dominicano. Misal romano completo, con lo propio de la Orden de Predicadores. Tomo I y II. Madrid: EDIBESA.

Ordinis Praedicatorum (MCMXLIX). Processionarium juxta ritum Sacri Ordinis Praedicatorum. Romae: Sancta Sabina.

Orden Tercera Seglar de Santo Domingo (1960). Manual del Terciario Dominico. Medellín: Bedout (Contiene el "Oficio Parvo de la Bienaventurada Virgen María", p.39-196).

Paulo VI (1974). Exhortación apostólica Marialis cultus. Roma: Vaticano.

Pio V, Bula (17-9-1569). Consueverunt romani pontífices. Roma: Vaticano.

Provincia de San Luis Bertrán de Colombia (2000). Completorio Dominicano. Bogotá: Curia provincial.

Staid, E. D. (1989). Rosario, en De Fiores y ..., pp. 1731-1741.

Susón, E. (2001). Autobiografía espiritual (vita). Salamanca: San Esteban (Introducción, traducción y notas de Salvador Sandoval).

Vicaire, M. H. (1964). Historia de Santo Domingo. Barcelona: Juan Flors, editor. (Versión española del original francés, por A. Velasco, O.P. y A. Conchado, O.P.) 